\title{
A decade of glaciological and meteorological observations in the Arctic (Werenskioldbreen, Svalbard)
}

Dariusz Ignatiuk ${ }^{1}$, Małgorzata Błaszczyk ${ }^{1}$, Tomasz Budzik ${ }^{1}$, Mariusz Grabiec ${ }^{1}$, Jacek A. Jania ${ }^{1}$, Marta Kondracka $^{1}$, Michał Laska ${ }^{1}$, Łukasz Małarzewski ${ }^{1}$, Łukasz Stachnik ${ }^{2}$

$5 \quad{ }^{1}$ University of Silesia in Katowice, Katowice, 40-007, Poland

${ }^{2}$ University of Wrocław, Wrocław, 50-137, Poland

Correspondence to: Dariusz Ignatiuk (dariusz.ignatiuk@us.edu.pl)

Abstract. The warming of the Arctic climate is well documented, but the mechanisms of Arctic amplification are still not fully understood. Thus, monitoring of glaciological and meteorological variables and the environmental response to accelerated climate warming must be continued and developed in Svalbard. Long-term meteorological observations carried out in situ on glaciers in conjunction with glaciological monitoring are rare in the Arctic and significantly expand our knowledge about processes in the polar environment. This study presents the unique glaciological and meteorological data collected in 20092020 in southern Spitsbergen (Werenskioldbreen). The meteorological data are comprised of air temperature, relative humidity, wind speed and direction, shortwave and longwave upwelling and downwelling radiation on 10 minutes, hourly and daily timescale (2009-2020). The snow dataset includes 49 sampling points from 2009-2019 with the snow depth, snow bulk density and SWE data. The glaciological data consist of point and surface annual winter, summer and net balance for 20092020. The paper also includes modelling of the daily glacier surface ablation (2009-2020) based on the presented data. The high-quality and long-term datasets are expected to serve as accurate forcing data in hydrological and glaciological models and validation of remote sensing products. The datasets are available from the and Polish Polar Database (https://ppdb.us.edu.pl/) and Zenodo (https://doi.org/10.5281/zenodo.5791748, Ignatiuk, 2021a; https://doi.org/10.5281/zenodo.5792168, Ignatiuk, 2021b).

\section{Introduction}

Long-term meteorological observations carried out in situ on glaciers in conjunction with glaciological monitoring are rare in the Arctic and significantly expand our knowledge about processes in the polar environment. Terrestrial meteorological monitoring alone does not always adequately address the needs of validation and calibration of numerical models or satellite products regarding glaciers. The warming of the Arctic climate is well documented, but the mechanisms of Arctic amplification are still not fully understood (IPCC, 2019). Both climate and ocean variables have fluctuated in Svalbard in the last decades (Isaksen et al., 2016; Walczowski et al., 2017, Nordli et al., 2014; Osuch and Wawrzyniak, 2017, Wawrzyniak and Osuch, 2020), which causes progressive and ongoing changes in the cryosphere (Nuth et al., 2019; Box et al., 2018; Błaszczyk et al., 
https://doi.org/10.5194/essd-2021-464

Preprint. Discussion started: 5 January 2022

(c) Author(s) 2022. CC BY 4.0 License.

was the year with the warmest summer in the history of instrumental observations in Svalbard (the mean JJA temperature was $7.2^{\circ} \mathrm{C}$, about $3^{\circ} \mathrm{C}$ above the climatological normal at the Svalbard Airport meteorological station). In Hornsund the same summer months mean was $4.8^{\circ} \mathrm{C}$ (only $1.2^{\circ} \mathrm{C}$ higher than the local normal). The hottest max air temperature ever was recorded on July 25th, 2020: $21.7^{\circ} \mathrm{C}$ and $16.5^{\circ} \mathrm{C}$ at Svalbard Airport and the Polish Polar Station in Hornsund, respectively (SIOS data access portal https://sios-svalbard.org/, Meteorological bulletin Spitsbergen-Hornsund, https://hornsund.igf.edu.pl/weather/). Moreover, the sea ice area on the Arctic Ocean reached the second minimal extent in the history of satellite measurements since 1979. While the summer of 2021 was colder and the minimal Arctic sea ice extent significantly larger, acceleration of the climate warming trend is proved despite interannual variations (Hanssen-Bauer et al., 2019). Such acceleration causes significant changes in the cryosphere of Svalbard and is particularly reflected in the faster melting of glaciers and thawing of the permafrost. It also stimulates faster energy and mass exchange between the atmosphere, cryosphere and ocean. The above examples of disparities in meteorological parameters demonstrate regional differences in climate warming and subsequently response of other environmental components. Thus, monitoring of such parameters and the environmental response to accelerated climate warming must be continued and developed in Svalbard. Long-term observations allow for better quantification of observed changes and facilitate their more profound understanding. This study presents the unique Arctic glaciological and meteorological data collected in 2009-2020 in southern Spitsbergen.

\section{Study Area}

Werenskioldbreen is well-studied, polythermal glacier located in South Spitsbergen (Svalbard) (Baranowski, 1982; Pälli et al., 2003; Grabiec et al.., 2012; Ignatiuk et al., 2014; Stachnik et al., 2016a; Stachnik et al., 2016b; Sułowicz et al., 2020). This valley-type glacier covers an area of $27.1 \mathrm{~km}^{2}$ in 2008 (Ignatiuk et al., 2014) and $25.7 \mathrm{~km}^{2}$ in 2017 (current study) in a catchment area of $44 \mathrm{~km}^{2}$. Werenskioldbreen is divided by a medial moraine into Slyngfjellbreen and the main stream of Werenskioldbreen flowing down from Skilryggbreen accumulation area (Figure 1). The internal marginal zone of the glacier is closed by a distinct arc of the ice-cored terminal moraine with one river gorge. Such a hydrological system allows the glacier basin to be treated as a closed research laboratory for many hydrological and interdisciplinary studies (Majchrowska et al., 2015; Stachnik et al., 2016b; Łepkowska and Stachnik, 2018; Gwizdała et al., 2018; Stachnik et al., 2019). The glacier is situated $15 \mathrm{~km}$ to the north from the Polish Polar Station Hornsund. The Stanisław Baranowski Spitsbergen Polar Station (University of Wrocław), a small field station is located at the southern edge of the Werenskioldbreen terminal moraine. Both facilities greatly simplify the accessibility and logistics of research and monitoring projects. 


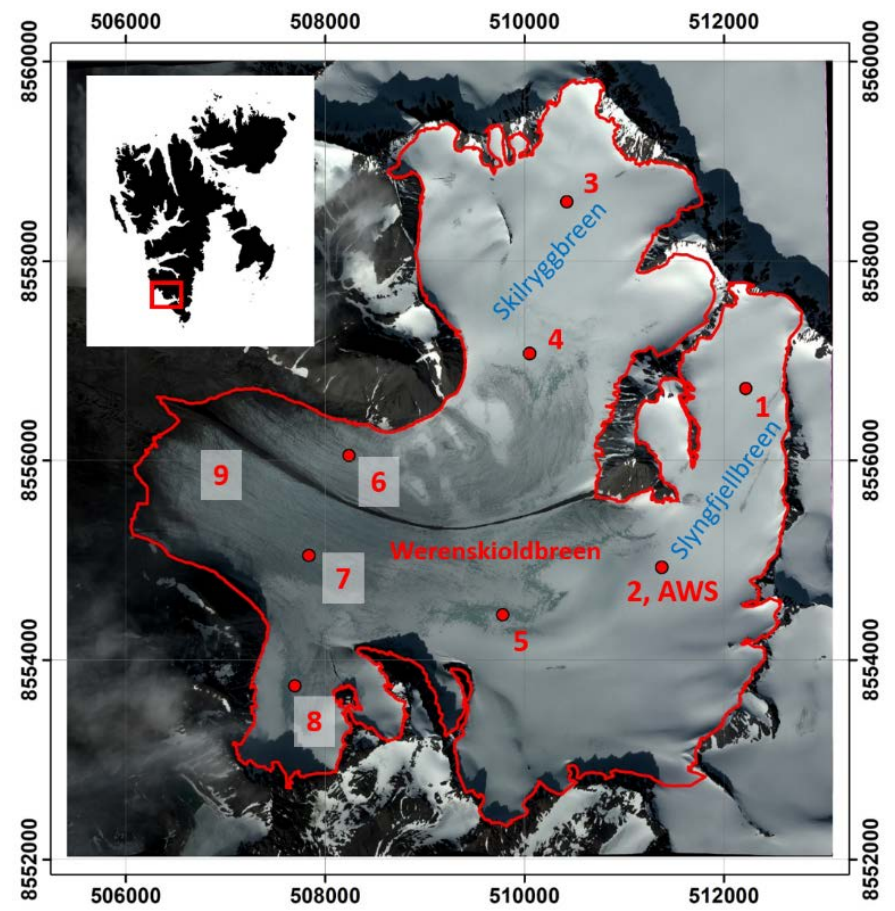

60 Figure 1: Location of mass-balance stakes (1-9) in 2009-2020 and the automatic weather station (AWS) on Werenskioldbreen (background: GeoEye, 2010/08/10)

\section{Instruments and methodology:}

\subsection{Meteorological monitoring}

The automatic weather station (AWS) is located at an altitude of $380 \mathrm{~m}$ above sea level (Figure 1), close to the average

65 equilibrium line altitude (ELA) for the years 1959 - 2008 (Noël et al, 2020). The station was installed on the glacier on 15 April 2010. The AWS was mounted on a long steel mast placed in the ice drilling hole (ca. $6 \mathrm{~m}$ deep). In the following years, as ablation progressed, the sensors were lowered or the mast was replaced with a new one in close proximity to the original location. The recording of variables (air temperature, humidity, wind speed, shortwave and longwave radiation) has started on 17 April 2010 (Table 1). The CNR4 net radiometer was replaced in 2016 by the CMP3 pyranometers, which resulted in

70 shortwave radiation measurements being continued and longwave radiation measurements being ceased. The Kipp \& Zonnen CNR4 consists of two CM3 pyranometers, two CG3 pyrgeometers and temperature sensors (PT100). Pyranometers (180o solid angle) have a glass dome and measure radiation in the range from 300 to $2800 \mathrm{~nm}$. One of the pyranometers directed upwards measures downwelling radiation, and the second one upwelling which measures solar radiation reflected from the earth's surface. Pyrgeometers ( $150^{\circ}$ solid angle), has silicone windows, which allow radiation measurements in the range from 4500 to $42000 \mathrm{~nm}$. Like the pyranometers, the pyrgeometers point in opposite directions (upwards and downwards). One of the 
https://doi.org/10.5194/essd-2021-464

Preprint. Discussion started: 5 January 2022

(c) Author(s) 2022. CC BY 4.0 License.

pyrgeometers measures the long-wave radiation coming from the atmosphere, the second one the long-wave radiation from the ground surface. In 2016, the A100R cup anemometer was replaced with the Gill WindSonic sensor, which allowed for measuring wind direction and speed. Changes in snow depth were recorded using an ultrasonic sensor SR50/SR50A developed by Campbell Scientific Ltd. This sensor is based on a $50 \mathrm{kHz}$ acoustic signal, applied with a temperature correction, and records the distance between the ground and the sensor level. Damaged sensors were systematically replaced to maintain data continuity.

Table 1. Automatic weather station (AWS) sensors specification (Werenskioldbreen, Svalbard)

\begin{tabular}{|c|c|c|c|c|}
\hline Variable & Sensor/producer & Operating range & Accuracy & $\begin{array}{l}\text { Period of } \\
\text { operation }\end{array}$ \\
\hline Air temperature & $\begin{array}{l}\text { 107/Campbell } \\
\text { Scientific }\end{array}$ & $-40-50^{\circ} \mathrm{C}$ & $\pm 0.2^{\circ} \mathrm{C}$ & $\begin{array}{l}04 / 2010- \\
05 / 2016\end{array}$ \\
\hline Air temperature & $\begin{array}{l}\text { HMP155 } \\
\text { (PT100)/Vaisala }\end{array}$ & $-80-60^{\circ} \mathrm{C}$ & $-80^{\circ}-20^{\circ} \mathrm{C}$ & $\begin{array}{l}05 / 2016- \\
05 / 2020\end{array}$ \\
\hline Relative humidity & HМР45АC/НОВО & $0-100 \% \mathrm{RH}$ & $\begin{array}{l} \pm 2 \%(0-90 \%) \\
\pm 3 \%(90-100 \%)\end{array}$ & $03-09 / 2011$ \\
\hline Relative humidity & $\begin{array}{l}\text { HMP155 (HUMICAP } \\
\text { R2)/Vaisala }\end{array}$ & $0-100 \% \mathrm{RH}$ & $\begin{array}{l} \pm 0.6 \% \text { RH }(0 \ldots 40 \% \mathrm{RH}) \\
\pm 1.0 \% \mathrm{RH}(40 \ldots 95 \% \mathrm{RH})\end{array}$ & $\begin{array}{l}5 / 2016- \\
12 / 2019\end{array}$ \\
\hline Wind speed & $\begin{array}{l}\text { A100R/Vector } \\
\text { Instruments }\end{array}$ & $0-75 \mathrm{~m} / \mathrm{s}$ & $\begin{array}{l} \pm 0.1 \mathrm{~m} / \mathrm{s}(0.3-10 \mathrm{~m} / \mathrm{s}) \\
\pm 1 \%(10-55 \mathrm{~m} / \mathrm{s}) \\
\pm 2 \%(>55 \mathrm{~m} / \mathrm{s})\end{array}$ & $\begin{array}{l}\text { 09/2010- } \\
05 / 2016\end{array}$ \\
\hline Wind speed & $\begin{array}{l}\text { WindSonic-1 / Gill } \\
\text { Instruments }\end{array}$ & $0-60 \mathrm{~m} / \mathrm{s}$ & $\pm 2 \%$ (at $12 \mathrm{~m} / \mathrm{s})$ & $\begin{array}{l}05 / 2016- \\
12 / 2019\end{array}$ \\
\hline Wind direction & $\begin{array}{l}\text { WindSonic-1/Gill } \\
\text { Instruments }\end{array}$ & $0-359^{\circ}$ & $\pm 3^{\circ}($ at $12 \mathrm{~m} / \mathrm{s})$ & $\begin{array}{l}05 / 2016- \\
05 / 2020\end{array}$ \\
\hline $\begin{aligned} \text { Radiation } & \\
\text { - } & \text { shortwave: } \\
& \text { downwelling } \\
& \text { and upwelling } \\
\text { - } & \text { longwave: } \\
& \text { downwelling } \\
& \text { and upwelling }\end{aligned}$ & CNR4 /Kipp\&Zonen & $\begin{array}{l}\text { Shortwave: } \\
300 \text { - } 2800 \text { nm } \\
\text { Longwave: } \\
4500 \text { - } 42000 \\
\mathrm{~nm}\end{array}$ & $\begin{array}{l}\text { Pyranometer: Uncertainty in } \\
\text { daily total }<5 \% \\
\text { Pyrgeometer: Uncertainty in } \\
\text { daily total }<10 \% \\
\pm 6 \%\left(-40-80^{\circ} \mathrm{C}\right) \\
\pm 25 \mathrm{~W} \mathrm{~m}^{-2} \text { at } 1000 \mathrm{~W} \mathrm{~m}^{-2}\end{array}$ & $\begin{array}{l}09 / 2010- \\
05 / 2016\end{array}$ \\
\hline $\begin{array}{l}\text { Downwelling } \\
\text { shortwave radiation }\end{array}$ & $\begin{array}{l}\text { SP1110/Skye } \\
\text { Campbell Scientific }\end{array}$ & $350-1100 \mathrm{~nm}$ & $\pm 5 \%$ (typically < 3\%) & $\begin{array}{l}05 / 2016- \\
05 / 2020\end{array}$ \\
\hline Datalogger & $\begin{array}{l}\text { CR1000/Campbell } \\
\text { Scientific }\end{array}$ & $-40-50^{\circ} \mathrm{C}$ & & $\begin{array}{l}04 / 2010- \\
05 / 2020\end{array}$ \\
\hline $\begin{array}{l}\text { Ablation and } \\
\text { accumulation }\end{array}$ & $\begin{array}{l}\text { SR50/Campbell } \\
\text { Scientific }\end{array}$ & $0.5-10 \mathrm{~m}$ & $\pm 1 \mathrm{~cm}$ or $0.4 \%$ & $\begin{array}{l}9 / 2010- \\
12 / 2019\end{array}$ \\
\hline
\end{tabular}


https://doi.org/10.5194/essd-2021-464

Preprint. Discussion started: 5 January 2022

(c) Author(s) 2022. CC BY 4.0 License.

In the 2010/2011 season, data recording by the logger was performed every $1 \mathrm{~min}$. Due to high energy demand during the polar night, the sampling time was changed to an instantaneous measurement every 10 minutes. Calibration and testing of sensors were performed regularly during spring expeditions based on the infrastructure of the Polish Polar Station Hornsund.

\subsection{Glaciological monitoring}

In 2009-2010, nine mass-balance stakes were installed on the Werenskioldbreen. The location was chosen to cover all the glacial zones as well as to create longitudinal profiles along the northern and southern parts of the glacier (Figure 1). The stakes net covered the glacier zones from $117 \mathrm{~m}$ a.s.l. to $515 \mathrm{~m}$ a.s.l. The stakes, 6 to 8 meters long, were embedded in the glacier by

90 a steam drilling rig or by Kovacs Ice Coring System. The mass-balance stakes were measured twice a year (spring-autumn, 2009-2013) during the winter maximum accumulation (April-May) and at the end of the ablation season or once a year (spring, since 2014). The amount of winter accumulation was determined during the spring campaigns. The parameters of snow cover (bulk snow density, snow depth, SWE - snow water equivalent) were measured in snow pits (a $100 \mathrm{~cm}^{3}$ snow gauge by Winter Engineering was used to determine the snow density of subsequent layers) or shallow core boreholes (Kovacs). During the measurements, repeated soundings of the snow depth were also performed with avalanche probes. In the absence of the autumn campaign, boreholes have been drilled on each stake in order to accurately determine the amount of summer ablation and possible summer accumulation. In the case of availability of data from the SR50A sensor, ablation or accumulation corrections were also made if the winter or summer season ended later than the date of field observations. In the years 2009-2011, the positions of the stakes were measured with precise GNSS receivers LEICA 1230 to determine glacier velocity. A portion of the ablation stakes have been damaged every few years. They have been broken by wind, polar bears, melt out from the ice or been buried by snow. The network of ablation stakes was supplemented and renovated as part of ongoing research and projects. Unfortunately, recent years have resulted in large gaps in measurements due to the pandemic travel restrictions. Detailed information on the temporal availability of glaciological data is presented in Table 2.

105 Table 2. Overview of mass balance and snow cover measurements on ablation stakes and infrastructure maintenance in years 2009-2020 on Werenskioldbreen (Svalbard), where: S - spring campaign (winter balance, April-May), A - autumn campaign (summer balance, August-September, can be performed next year spring), X - lack of stake, SP - snow pit (SWE data), KD Kovacs drilling (SWE data), G - GPS measurements, SR50 - automatic measurements at AWS.

\begin{tabular}{|c|c|c|c|c|c|c|c|c|c|}
\hline Stake no. & 1 & 2 (+AWS) & 3 & 4 & 5 & 6 & 7 & 8 & 9 \\
\hline $\begin{array}{c}\text { Coordinates } \\
\text { (UTM } \\
\text { 33N), } \\
\text { height } \\
\text { (geoid } \\
\text { EGM_96) }\end{array}$ & $\begin{array}{c}8556724.663 \\
512219.566 \\
515\end{array}$ & $\begin{array}{c}\text { 8554930.167, } \\
\text { 510423,846; } \\
384\end{array}$ & $\begin{array}{c}\text { 8558594.6, } \\
\text { 510423.846; } \\
471\end{array}$ & $\begin{array}{c}\text { 8557076.138, } \\
510048.921 ; \\
392\end{array}$ & $\begin{array}{c}\text { 8554448.524, } \\
\text { 509786.006; } \\
308\end{array}$ & $\begin{array}{c}8556047.777 \\
508243.448 \\
188\end{array}$ & $\begin{array}{c}8555045.023 \\
507837.608 \\
199\end{array}$ & $\begin{array}{c}8553738.705 \\
507697.579 \\
277\end{array}$ & $\begin{array}{c}\text { 506449.264, } \\
8555956.882 ; \\
120\end{array}$ \\
\hline 2009 & S, A, SP, G & S, A, SP, G & S, A, SP, G & S, A, SP, G & S, A, SP, G & S, A, SP, G & S, A, SP, G & S, A, SP, G & $\mathrm{X}$ \\
\hline 2010 & S, A, SP, G & S, A, SR50, G & $\mathrm{S}, \mathrm{A}, \mathrm{G}$ & $\mathrm{S}, \mathrm{A}, \mathrm{G}$ & S, A, SP, G & $\mathrm{S}, \mathrm{A}, \mathrm{G}$ & S, A, SP, G & $\mathrm{S}, \mathrm{A}, \mathrm{G}$ & S, A, SP, G \\
\hline 2011 & S, A, SP, G & S, A, SR50, G & $\mathrm{S}, \mathrm{A}, \mathrm{SP}, \mathrm{G}$ & S, A, SP, G & $\mathrm{S}, \mathrm{A}, \mathrm{G}$ & $\mathrm{S}, \mathrm{A}, \mathrm{G}$ & S, A, SP, G & S, A, SP, G & $\mathrm{S}, \mathrm{A}, \mathrm{G}$ \\
\hline
\end{tabular}


https://doi.org/10.5194/essd-2021-464

Preprint. Discussion started: 5 January 2022

(c) Author(s) 2022. CC BY 4.0 License.

(c) (1)

\begin{tabular}{|c|c|c|c|c|c|c|c|c|c|}
\hline 2012 & S, A & $\begin{array}{c}\text { S, A, SP, } \\
\text { SR50 }\end{array}$ & S-X, A & S-X, A & S-X, A & S, A & S, A, SP & S, A & S, A \\
\hline 2013 & S-X, A-X, & X, SR50 & $\mathrm{S}, \mathrm{KD}, \mathrm{A}$ & $\mathrm{S}, \mathrm{KD}, \mathrm{A}$ & S-X, A-X, & S, KD, A & S, SP, & $\mathrm{S}, \mathrm{KD}$, & S-X, A \\
\hline 2014 & S, A, SP, & X, SR50 & S, A & S, A & S, A-X, SP & S, A & S, A, SP, & S, A & S, A-X \\
\hline 2015 & S, A-X, SP, & X, SR50 & S, A & S, A & S, A, SP & S, A & S, A & S, A-X & S, A-X, SP \\
\hline 2016 & S, A-X, KD, & $\mathrm{X}, \mathrm{KD}$, SR50 & S, A & S, A & S-X, A-X, & S, A-X & S, A & S, A & S-X, A-X \\
\hline 2017 & $\mathrm{~S}, \mathrm{~A}$, & $\mathrm{X}, \mathrm{KD}, \mathrm{SR} 50$ & S, A, KD & $\mathrm{S}, \mathrm{A}, \mathrm{KD}$ & $\mathrm{S}, \mathrm{A}, \mathrm{KD}$ & $\mathrm{X}, \mathrm{A}$ & $\mathrm{S}, \mathrm{A}, \mathrm{KD}$ & S, A & S, A-X, KD, \\
\hline 2018 & $\mathrm{~S}-\mathrm{X}, \mathrm{A}, \mathrm{KD}$, & $\mathrm{X}, \mathrm{KD}$, SR50 & S, A, KD & $\mathrm{S}, \mathrm{A}, \mathrm{KD}$ & S, A & $\mathrm{X}$, & $\mathrm{S}, \mathrm{A}, \mathrm{KD}$ & $\mathrm{X}$, & $\mathrm{S}, \mathrm{A}, \mathrm{KD}$ \\
\hline 2019 & $\mathrm{X}, \mathrm{KD}$ & $\mathrm{X}, \mathrm{KD}, \mathrm{SR} 50$ & S-X, & $\mathrm{S}, \mathrm{A}$ & $\mathrm{S}, \mathrm{KD}, \mathrm{A}$ & $\mathrm{X}$, & $\mathrm{X}, \mathrm{KD}$ & $\mathrm{X}$, & $\mathrm{S}, \mathrm{A}, \mathrm{KD}$ \\
\hline 2020 & $\mathrm{~s}$ & $\mathrm{X}$ & S & S & S & $\mathrm{X}$ & $\mathrm{S}$ & $\mathrm{X}$ & $\mathrm{S}$, \\
\hline
\end{tabular}

110 Based on the data collected, the following glaciological variables are available: annual and seasonal point ablation and accumulation, snow depth, bulk snow density and SWE (snow water equivalent) at the measuring points, surface mass balance and data from automatic measurements (AWS) of ablation and accumulation by the SR50 sonic distance sensor (Campbell Scientific, SR50-L and SR50A-L, https://www.campbellsci.com/sr50).

The analyses of the glacier's surface mass balance excepted field measurements were based on altitude zones determined from

115 digital elevation models (DEM). Two DEMs with geoidal height (EGM2008) were used, one generated from SPOT image acquired on 1 September 2008 (Ignatiuk et al., 2014) and Pleiades high-resolution images taken on 20 August 2017 (Błaszczyk et al., 2019).

\section{Meteorological observations}

\subsection{Air temperature and radiation}

120 The air temperature data forms the most homogeneous series for 2010-2016 (Figure 2a). In 2017-2020 the data gaps were already significant due to failure of the instruments and the lack of servicing due to travel restrictions caused by the COVID19 pandemic. Also, for 2010-2016, net radiation balance data (short- and long-wave radiation) are available (Figure 2b,c). In 2017-2020, radiation data included only downwelling shortwave radiation. 

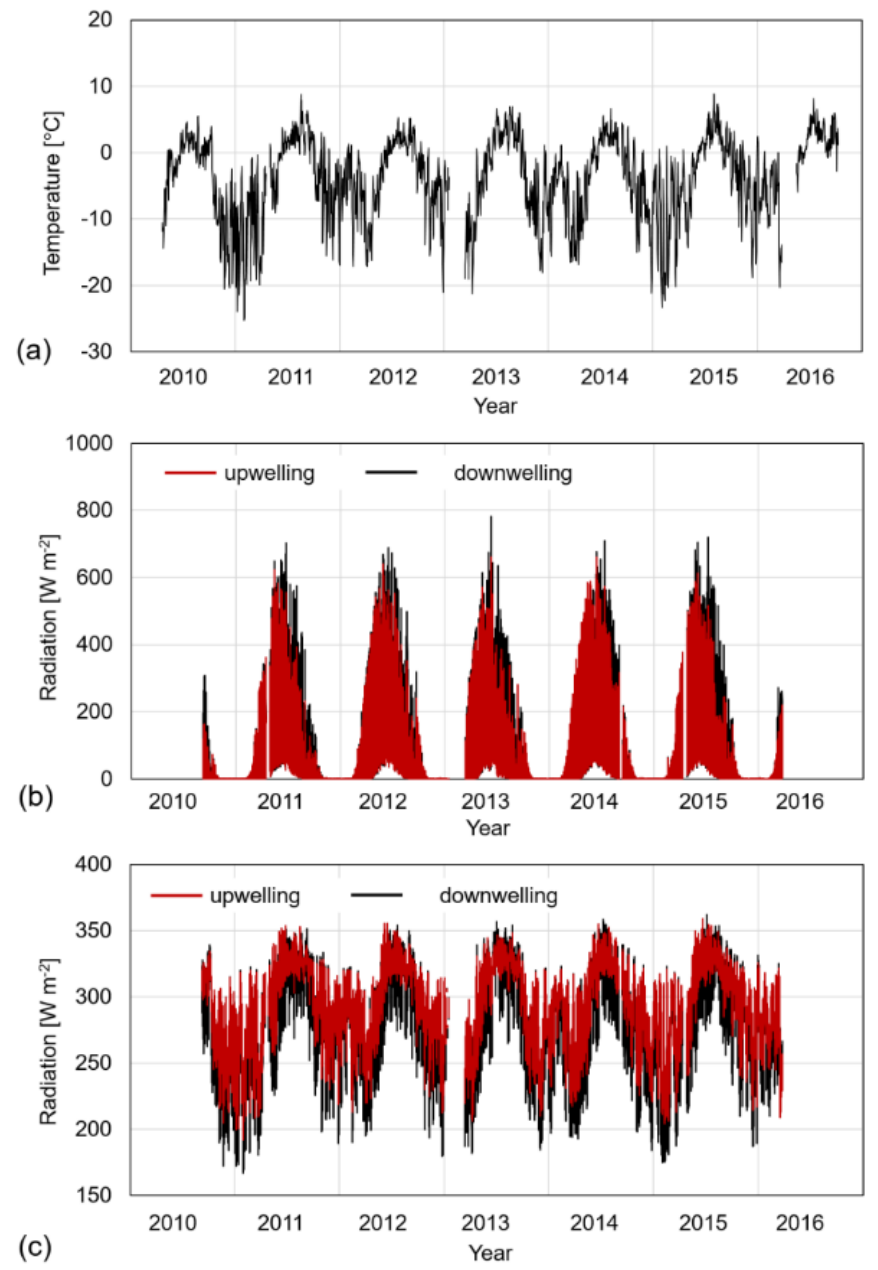

125 Figure 2: Time series of meteorological variables from 2010 to 2016 on Werenskioldbreen, including daily average air temperature (a), hourly average shortwave radiation (b) and hourly average longwave radiation (c) for downwelling (black line) and upwelling (red line) radiation.

For years with full data continuity (Figure 2a), air temperature monthly and yearly averages were calculated and then compared with the data from the Polish Polar Station Hornsund (Wawrzyniak and Osuch, 2020). The average difference in the annual temperature (2011, 2012, 2014, 2015) on the glacier (380 m a.s.l.) and the Polish Polar Station Hornsund (8 m a.s.l.) was $2.7^{\circ} \mathrm{C}$, which gives an average temperature lapse rate $0.72 / 100 \mathrm{~m}$. The air temperature increased by $0.09^{\circ} \mathrm{C}$ per year, which is over five times faster than the global average of $0.17^{\circ} \mathrm{C}$ per decade (NOAA, 2020). More importantly, a twice as high trend of $0.2^{\circ} \mathrm{C}$ per year is recorded for the summer months (JJA) when glaciers melt most rapidly. Downwelling shortwave radiation reaches its maximum during the middle of the polar day (June). Its annual course is governed by the occurrence of polar day 135 and night, while its daily course is governed by cloudiness and the height of the sun above the horizon. The reflected shortwave 
https://doi.org/10.5194/essd-2021-464

Preprint. Discussion started: 5 January 2022

(c) Author(s) 2022. CC BY 4.0 License.

(c) (i)

radiation (upwelling) is a function of the surface albedo. In the spring and early summer, we observed the highest values of reflected radiation due to the presence of snow cover on the glacier. In the further part of the ablation season (July-August), we noticed a sudden decrease in reflected radiation (Figure $2 \mathrm{~b}$ ) as a result of the disappearance of snow cover at the measurement site (AWS) and the appearance of glacial ice on the surface. The decrease in upwelling shortwave radiation can be slight (e.g. 2012) when the melting of snow cover occurs mainly as a result of surface ablation or abrupt (e.g. 2015) when significant rainfall led to a sudden change in the albedo on the glacier. The maximum values of downwelling/upwelling longwave radiation (Figure 2c) usually occurred in summer and autumn. The values in winter and spring are lower, which in general shows similar patterns with the seasonal variations in air temperature.

\subsection{Other variables}

145 In 2009-2020, the AWS measured relative humidity, wind direction and speed, ablation and accumulation of snow. These sensors were installed at the station depending on the needs of the ongoing projects and doctoral dissertations. Not all of them could be connected to the datalogger at the same time. Due to their construction, these sensors are also less resistant to operation in polar conditions and to servicing only once a year, causing a higher failure rate for these sensors. Therefore, the data obtained for these variables are not continuous and not homogenous for the entire observation period. Nevertheless, these data are available and are of great value for solving specific scientific problems.

\section{Glaciological observations}

\subsection{Point ablation and accumulation}

Measurements on mass-balance stakes (Figure 1, Table 2) were performed in accordance with the recommendations and guidelines contained in the Glossary of Glacier Mass Balance and Related Terms (Cogley et al., 2011). After Cogley et al.

155 (2011) it was assumed that accumulation is always positive, while ablation is negative. Therefore, the calculation of the point mass balance is Eq. (1):

$b_{a}=c_{a}+a_{a}=b_{w}+b_{s}=c_{w}+a_{w}+c_{s}+a_{s}$,

where: ba - annual balance at a point, ca - annual accumulation, aa - annual ablation, bw - winter balance, bs - summer balance, cw - winter accumulation, aw - winter ablation, cs - summer accumulation, as - summer ablation

160 As it is difficult to measure the annual accumulation and annual ablation, the winter and summer balance were measured (including the winter and summer ablation and accumulation). The balance calculation was based on the physical parameters of snow and ice measured in the field (see Snow Water Equivalent). The error was estimated using the total differential function. 
https://doi.org/10.5194/essd-2021-464

Preprint. Discussion started: 5 January 2022

(c) Author(s) 2022. CC BY 4.0 License.

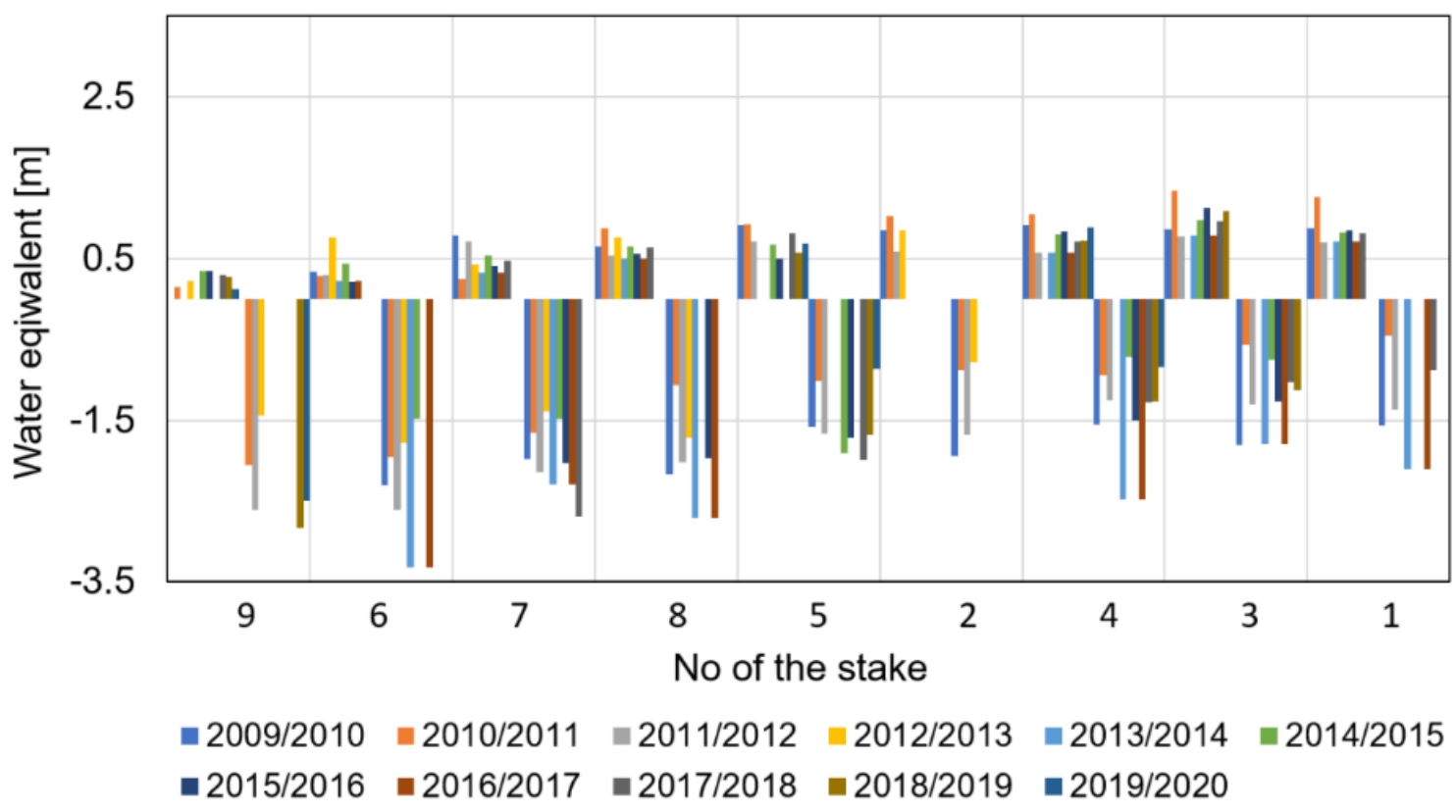

165 Figure 3: Winter and summer balance at the point on 1-9 mass-balance stakes in years 2009-2020 For the location/elevation of the stake see Figure 1 and Table 2.

The dataset includes point winter and summer mass balance measurements on mass-balance stakes in 2009-2020 and the calculated point annual mass balance. The data allow the analysis of the spatial and seasonal variability of accumulation and ablation at points on the glaciers at different altitudes. The analysis of the winter balance (Figure 3) shows the interannual fluctuations in snow accumulation in the entire altitude profile of the glacier. The analysis of point winter balance shows the smallest interannual fluctuations on the glacier snout (stake 9) and in the sheltered upper glacier cirque (stake 8). In the case of the point summer balance, the greatest interannual changes are observed in the middle zone of the glacier (200 - $400 \mathrm{~m}$ a.s.l.). This is due to a longer ablation period and higher temperatures not previously recorded at these altitudes. 


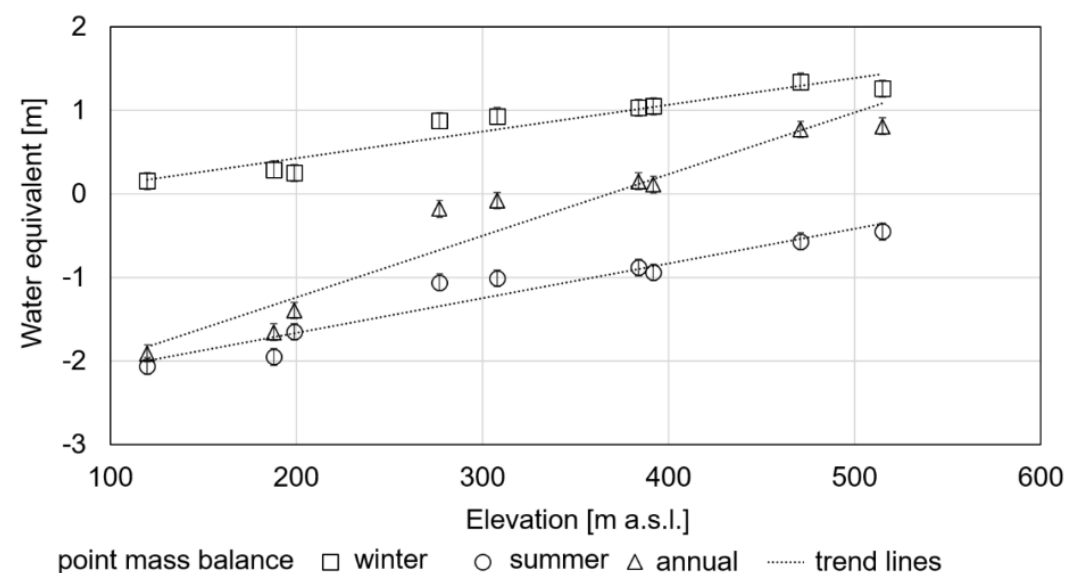

175 Figure 4: Examples of winter, summer and annual point mass balance on Werenskioldbreen (season 2010/2011). Whiskers show an error.

Each of the balance years can be considered separately (Figure 4). Winter accumulation in the analysed period was generally sparse. The last significant accumulation on Werenskioldbreen took place in 2011. A slight accumulation in the highest parts of the glacier was also observed in 2013, 2015 and 2020. Observations from 2020, however, may be biased by unqualified substitutive observers due to the pandemic situation. In all other years, the ELA was above the highest monitored stake, no 1 (Table 2). The data on point mass balance components are crucial for calculations of the general superficial mass balance of glaciers. These data have very high importance for different modelling purposes, e.g. hydrology and glacier drainage modelling, total water discharge from the glacier, sea level rise models and validation of remote sensing products.

\subsection{Snow Water Equivalent (SWE)}

185 In the years 2009-2019, 49 samplings (shallow drilling or snowpits) were made on the glacier during the spring measurement campaigns in order to determine the bulk snow density, and thus SWE. In the case of snowpit measurements, the density was measured for each homogeneous layer. The bulk snow density for the snow profile was then calculated based on a weighted average. Whereas the bulk snow density during the drilling of snow cores was calculated based on the length and weight of each core in the profile. The SWE was calculated after Sturm et al. (2010). The average density of snow cover ranges from

190386 to $447 \mathrm{~kg} \mathrm{~m}^{-3}$ (Table 3). The highest snow density values were noted in 2012. They are related to the extremely warm conditions in the winter season 2011/2012 with the heavy rainfall (Eupikasza et al., 2019) during the winter and caused probably by the inflow of warm Atlantic water (the fjords of south-west Spitsbergen did not freeze).

Table 3. Average snow depth and bulk snow density based upon data from sampling points (snow pits and drilling cores) on Werenskioldbreen in years 2009-2019. 


\begin{tabular}{cccccccccccc}
\hline Year & 2009 & 2010 & 2011 & 2012 & 2013 & 2014 & 2015 & 2016 & 2017 & 2018 & 2019 \\
\hline $\begin{array}{c}\text { Number of } \\
\text { sampling }\end{array}$ & 8 & 3 & 5 & 2 & 6 & 3 & 3 & 2 & 6 & 4 & 7 \\
$\begin{array}{c}\text { Average } \\
\text { snow depth } \\
\quad[\mathrm{m}]\end{array}$ & 1.79 & 1.90 & 1.65 & 1.35 & 1.06 & 1.73 & 1.57 & 1.90 & 1.64 & 1.53 & 1.60 \\
$\begin{array}{c}\text { Average } \\
\text { bulk snow } \\
\text { density } \\
{\left[\mathrm{kg} / \mathrm{m}^{3}\right]}\end{array}$ & 434 & 415 & 412 & 447 & 386 & 391 & 387 & 407 & 427 & 419 & 410 \\
\hline
\end{tabular}

195
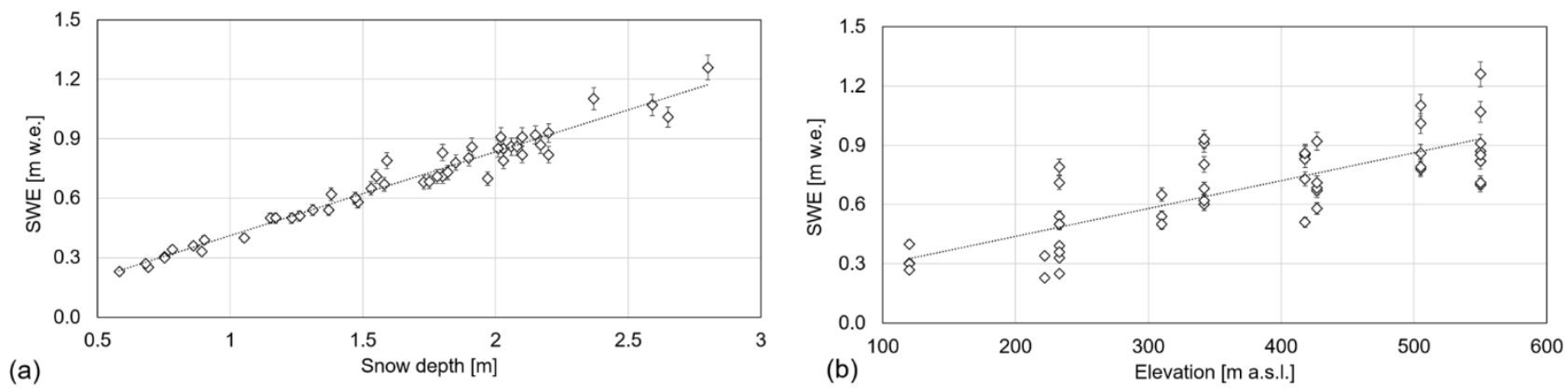

Figure 5: Relationship between SWE and snow depth (a) and SWE and elevation m a.s.l. (b). Whiskers show an error.

SWE values show a very high correlation with the snow depth $\left(R^{2}=0.96\right.$, Figure $\left.5 a\right)$ and the altitude above sea level $\left(R^{2}=\right.$ 0.62, Figure 5b). Uszczyk et al. (2019) found the relationship between the bulk snow density and the snow depth on Hansbreen located next to Werenskioldbreen. It was observed that the bulk snow density increases with snow depth. The long-term data collected on Werenskioldbreen has not confirmed this correlation. In fact, in some seasons it is the opposite, i.e. the lowthickness snow cover in the lower zones of the glacier has the highest bulk snow density. Seasonal variability can be explained by various meteorological conditions during the accumulation season. The differences between Werenskioldbreen and Hansbreen can most likely be explained by different orographic conditions and exposure, which affects snow blowing and snow deposition.

\subsection{Surface mass balance (SMB)}

While the mass balance is measured on many glaciers, the data series rarely exceeds 10 years (Schuler et al., 2020). Multiyear data series, such as those from Werenskioldbreen, represent a unique value for tracking long-term changes in the Arctic environment. Calculation of the SMB was based on point winter and summer balance analyses and digital elevation models. 210 The point measurements are extrapolated over the glacier surface determining the balance as a function of altitude and 
https://doi.org/10.5194/essd-2021-464

Preprint. Discussion started: 5 January 2022

(C) Author(s) 2022. CC BY 4.0 License.

averaging them, using the weights determined from the distribution of the glacier surface as a function of altitude (Cogley et al., 2011). The error was estimated using the total differential function.

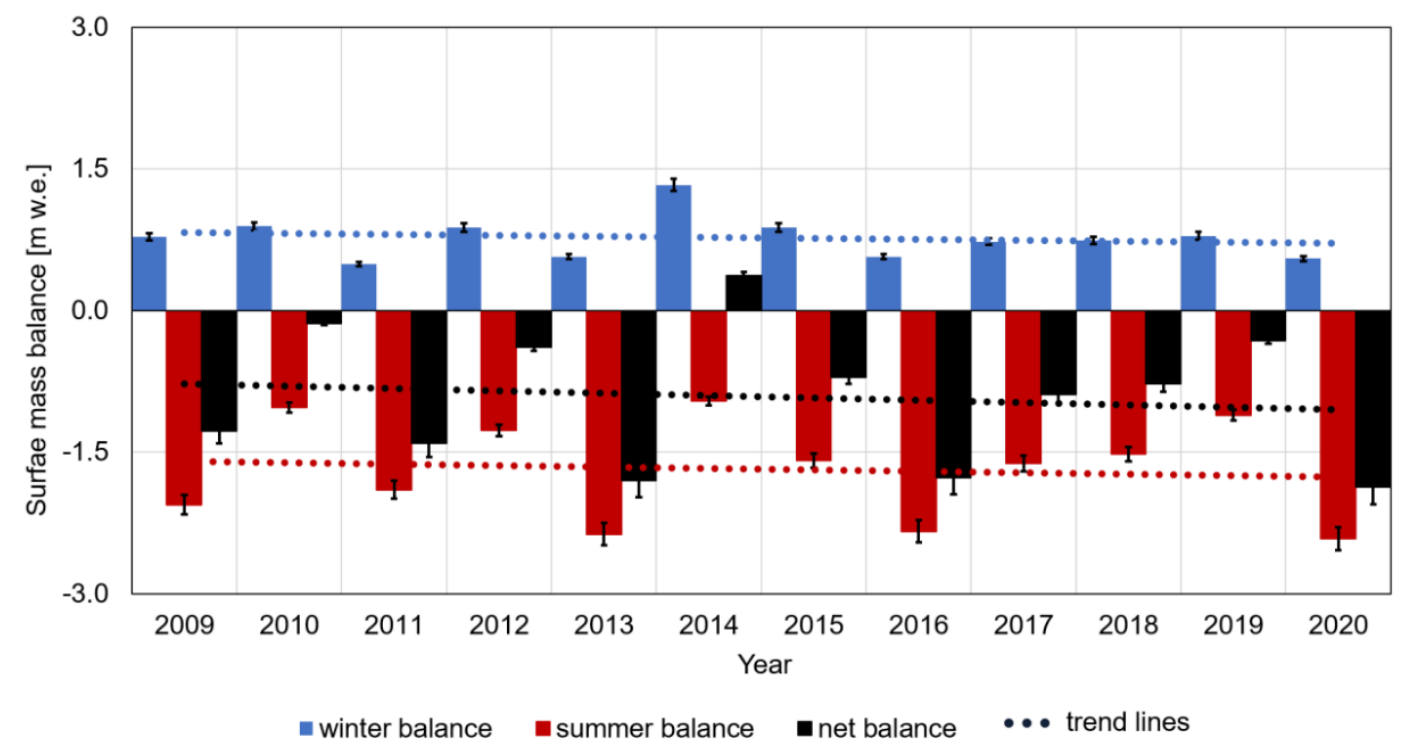

Figure 6: Annual surface mass balance and its components of Werenskioldbreen in 2009-2020. Blue bars - winter balance, red bars - summer balance, green bars - net balance. The results for 2019 may be understated (field measurements performed by the nonexpert crew).

The long-term trends in the summer and winter SMB indicate increasing summer ablation and decreasing winter accumulation. The largest fluctuations are observed in the summer balance, which depends on the interannual changes in the duration of the positive air temperatures and thus the length of the ablation season. The winter balance shows greater stability, however, over the decade, the trend in the amount of snow accumulation is downward. This entails a negative trend in the SMB of Werenskioldbreen (Figure 6). Based on the trend lines, it can be concluded that winter balance decreases by $0.09 \mathrm{~m}$ w.e. per decade, while the summer balance increases by $-0.14 \mathrm{~m}$ w.e. for a decade. This gives us an acceleration of the ablation (SMB) by $0.23 \mathrm{~m}$ w.e. for a decade on Werenskioldbreen.

Grabiec et al. (2012) has used monthly values of air temperature and precipitation from the meteorological station at Hornsund and the reanalysis ERA-40 data to hindcast the mass balance of Werenskioldbreen for the years 1959-2002. The average winter SMB for 1959-2002, depending on the model, was $0.81 \mathrm{~m}$ water equivalent (w.e.) (ERA-40 data) and $0.87 \mathrm{~m}$ w.e. (meteorological data) which, compared to the last decade (average winter SMB $0.77 \mathrm{~m}$ w.e.), decreased by 5 and $12 \%$ respectively. The summer SMB increased by 37\% in comparison to the meteorological model (from -1.23 m w.e. in 1959 2002 to -1.68 m w.e. in 2009-2020) and by 47\% for the ERA-40 data model (from -1.14 m w.e. in 1959-2002). Detailed analysis of summer SMB data from modelling (1979-2005) and observations (1999-2019) shows an increase in the average 10-year summer SMB from -1.16 m w.e. in 1979-1988, through -1.35 and -1.55 in 1989-1998 and 1999-2005, respectively, to 
-1.68 in 2009-2020. A natural consequence of increasing the summer SMB is also a much more negative SMB in the last decade (-0.92 m w.e.) compared to the years 1959-2002 (-0.35 m w.e. for meteorological data model and $-0.34 \mathrm{~m}$ w.e. for ERA-40 data model).

\subsection{Daily surface ablation}

The influence of air temperature on the glacier surface ablation has been the subject of numerous studies. The coefficient of determination between the annual ablation and the sum of positive daily air temperature was calculated as $0.96\left(R^{2}\right)$ by Braithwaite and Olsen (1989). High correlation is caused by the strong dependence between the air temperature and the components of the energy balance (Hock, 2003). Ohmura (2001) presented the physical basis for the application of temperature ablation models, the relationship between air temperature and long-wave radiation of the atmosphere, sensible heat and incident short-wave radiation. The basic temperature ablation model is given by the equation (Braithwaite, 1995):

$\sum_{i=1}^{n} M=D D F \sum_{i=1}^{n} T^{+} \Delta t$,

$D D F=\frac{M_{m} \cdot \varrho}{T^{+}}$

where $\mathrm{T}^{+}$- positive average daily temperature $[\mathrm{K}]$, DDF - the degree-day factor in $\mathrm{mm} \mathrm{d}^{-1} \mathrm{~K}^{-1}, \mathrm{M}_{\mathrm{m}}$ - measured ablation [m] , $\mathrm{M}$ - melting [m w.e.], $\varrho$ - density $\left[\mathrm{kg} \mathrm{m}^{-3}\right.$ ]. Melting is assumed to be zero when the air temperature is $\geq 0^{\circ} \mathrm{C}$.

On the basis of glaciological and meteorological data collected on Werenskioldbreen, daily surface ablation for May November 2009-2020 was calculated (Figure 7). The error was estimated using the total differential function. In the case of gaps in meteorological data collected by the AWS on Werenskioldbreen, data from the Polish Polar Station located $16 \mathrm{~km}$ south-east were used (Wawrzyniak and Osuch, 2020).

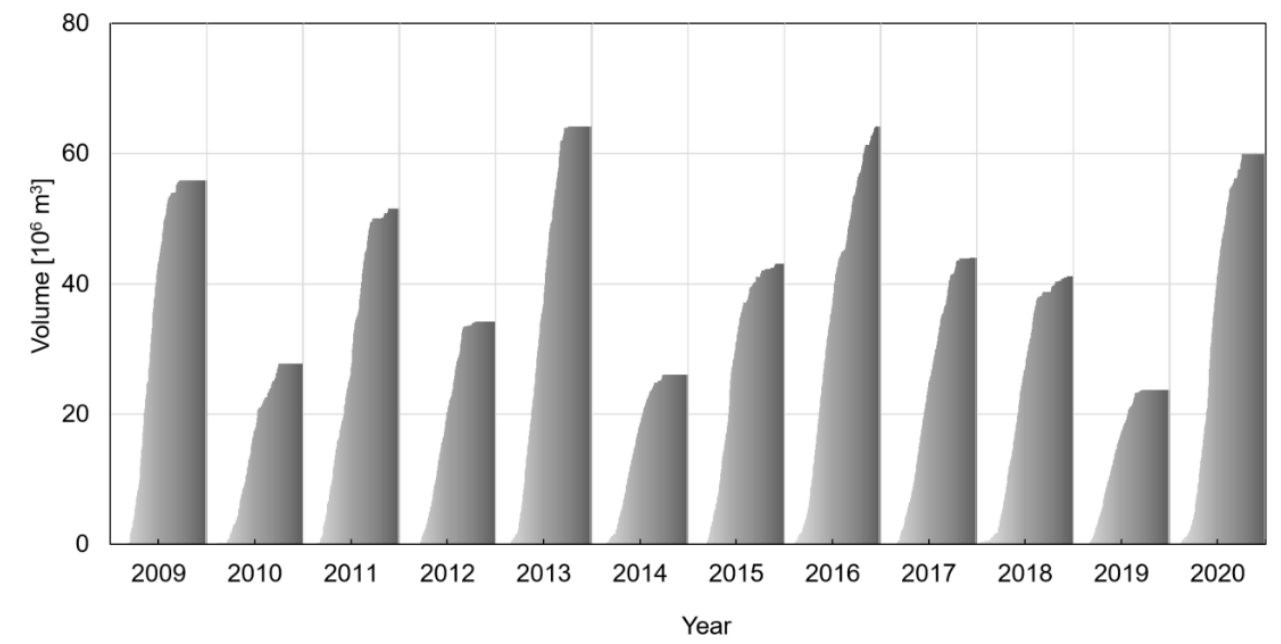

Figure 7: Calculated daily surface ablation $\left[10^{6} \mathrm{~m}^{3}\right]$ in May - November $(2009$ - 2020) for Werenskioldbreen. 
https://doi.org/10.5194/essd-2021-464

Preprint. Discussion started: 5 January 2022

(c) Author(s) 2022. CC BY 4.0 License.

Seasonal sums of surface ablation oscillate between about $23.7 \pm 1.7$ (2019) and $64.2 \pm 4.5 \cdot 10^{6} \mathrm{~m}^{3}$ (2013), with an average of $44.7 \pm 3.1 \cdot 10^{6} \mathrm{~m}^{3}$ for 2009-2020. The value in 2019 may be underestimated due to problems with field measurements caused by the pandemic travel restrictions. The length of the ablation season determines the size of ablative outflow. It varied in the analysed period from 134 days in 2014 to 203 days in 2016 (the average for 2009-2020 was 163 days). The surface ablation is affected by the decrease in the number of sunny days and the increase of days with precipitation and cloud cover (Wawrzyniak and Osuch, 2020). The amount of water produced by surface ablation is the largest component of the total runoff from the catchment but precipitation can also be an important element of the water balance (Majchrowska et al., 2015).

\section{Quality control and data processing}

Data quality assurance includes additional measurements and calibration of equipment performed during the observation period and post-processing of the collected data. The analysis differed for the meteorological data constituting the time series and for the glaciological data.

The first stage of quality control for meteorological data consisted in visualizing each of the measurement series and review to the disrupted data caused by interruptions in the operation of sensors. Due to its location, the automatic measurement station (AWS) operating on Werenskioldbreen could not be monitored with high frequency. As a result there were periodic problems with the power supply as well as with freezing of some sensors. Power shortages manifested themselves in the disappearance of measurements and the occurrence of isolated measurements, the correctness of which could not be confirmed, and therefore they were removed. Similarly, freezing of sensors manifested in 'blocking' the measurement at one value for a longer time. It mainly concerned wind speed and direction measurements. As such values are unnatural, they were identified as erroneous and removed from the set during visual inspection. The next stage of the control was the identification of individual measurements where the values were too different compared with the previous and following measurements and that did not fit in the short-term trend. These measuring pins were averaged with respect to adjacent measurements. It mainly concerned air temperature and humidity records, where such artefacts in the measurement series are unnatural. Similarly, the analysis of the measurement series was performed in terms of unnatural values, i.e. values exceeding the permissible variability of the relative humidity or air temperature. These were a few cases. In these situations, such values were eliminated or averaged over adjacent measurements. In the last step, the same variables were compared, but from different weather stations in Svalbard. Air temperature time series have been tested with observations at the Polish Polar Station Hornsund (Wawrzyniak and Osuch, 2020). Mainly, the correlations of the variability of parameters were checked in comparison to the stations accepted as reference. Nevertheless, it should be remembered that even in the case of close points, this correlation does not have to be high or consistent due to the specificity of these stations, i.e. different shading conditions, ground, topography or exposure.

Measurement series prepared and tested in such a way were used to calculate series with an hourly and daily resolution (24h). The series was created as a result of averaging or summing up depending on the parameter under development. In the case of wind direction, it was limited only to calculating the direction of the mean wind vector in hourly intervals. 
https://doi.org/10.5194/essd-2021-464

Preprint. Discussion started: 5 January 2022

(c) Author(s) 2022. CC BY 4.0 License.

Such prepared measurement series were saved in the NetCDF (Network Common Data Form) format and placed on the server supporting OPeNDAP (www.ppdb.us.edu.pl). The choice of this type of file is due to its universal nature. NetCDF files are in line with the modern trend of storing and publishing measurement series meeting the FAIR data principles. The collections are compliant with Unidata's Attribute Convention for Dataset Discovery (ACDD-1.3) and Climate and Forecast (CF) Conventions (CF-1.8). The Attribute Convention for Dataset Discovery identify and define a list of NetCDF global attributes recommended for describing a NetCDF dataset to discovery systems such as Digital Libraries. Software tools can use these attributes for extracting metadata from datasets, and exporting to Dublin Core, DIF, ADN, FGDC, ISO 19115 etc. metadata formats. The CF metadata conventions are designed to promote the processing and sharing files created with the NetCDF API. The conventions define metadata that provide a definitive description of what the data in each variable represents and the spatial and temporal properties of the data. This enables users of data from different sources to decide which quantities are comparable and facilitates building applications with powerful extraction, regridding, and display capabilities. The CF convention includes a standard name table, which defines strings that identify physical quantities. Global Attributes of prepared NetCDF files comply with the recommendations of The Arctic Data Center (ADC) which is a service provided by the Norwegian Meteorological Institute (MET) (https://adc.met.no/node/4).

All ACDD 1.3 Variable Attributes recommended were used. They were supplemented with the so-called_FillValue = -999.9 indicating data gaps and valid_max and valid_min describing the natural and allowed variability of these parameters in the measurement area. All measurement parameter names follow Climate and Forecast (CF) Standard Name Table version 77 which was available on the day when the dataset was published.

The keywords vocabulary used is consistent with the Global Change Master Directory (GCMD) Keywords (https://earthdata.nasa.gov/earth-observation-data/find-data/idn) developed for 20 years by The National Aeronautics and Space Administration (NASA)/gcmd-keywords) which are a hierarchical set of controlled Earth Science vocabularies that help ensure Earth science data, services, and variables are described in a consistent and comprehensive manner and allow for the precise searching of metadata and subsequent retrieval of data, services, and variables.

Glaciological data have different specifics than meteorological data. Glaciological data are not collected automatically in large amounts but are based on single, unique observations that must be made with great care as they are not possible to repeat or relate to observations from other areas.

310 Each measurement of the ablation stake was performed twice. If the funnel melts in ice or snow around the stake, the measurement was made to the theoretical flat surface joining the edges of the funnel. In the event of a stake skewing, its total length was measured and then, if possible, the stake was replaced with a new one. Measurements of the snow depth, apart from making snow pits or shallow drilling, were always verified by taking 2-3 measurements with an avalanche probe. In order to obtain comparable measurements of bulk snow density (and SWE) these measurements were performed with two different

315 methods (snow pit and shallow drilling), and a series of parallel measurements were performed showing that the difference in the calculated SWE does not exceed 5\%. In order to obtain the most accurate data from the Kovacs drill, the quality of the obtained ice and snow cores was checked in order to determine the precise diameter of the obtained cores. 
https://doi.org/10.5194/essd-2021-464

Preprint. Discussion started: 5 January 2022

(c) Author(s) 2022. CC BY 4.0 License.

(c) (i)

The obtained SMB and point mass balance calculations were compared with the data published by the World Glacier Monitoring Service (https://wgms.ch) for other glaciers on Svalbard in order to verify the consistency of trends and qualitative and quantitative control. Data on surface ablation in seasons where it was possible were controlled by comparison with the data collected by the SR50 (sonic ranger) sensor, which was also used to verify the duration of the ablation season. Measurements during the autumn campaign did not always take place after or at the end of the ablation season. This was due to the logistics of the expeditions and the extension of the ablation season. An SR50 sensor was used to control the quality of the collected ablation data, or additional drillings were made during the next spring expedition to verify the ablation data collected in the previous year. The glaciological data were saved in the CSV and NetCDF formats using GCMD keywords vocabulary.

The quality of DEM generated from the SPOT images in 2008 was validated with the height of stakes on Werenskioldbreen (Ignatiuk et al., 2014). The median value and standard deviation of the accuracy of the DEM were $-0,85 \mathrm{~m}$ and $2.2 \mathrm{~m}$, respectively. Validation of the DEM generated from Pleiades images taken in 2017 was based on stake positions over neighbouring Hansbreen (Błaszczyk et al. 2019). The median value and standard deviation of DEM accuracy were -0,36 m and $0.24 \mathrm{~m}$, respectively.

\section{Data availability}

The data is stored in two repositories that provide long-term availability, open access, DOI and license according to the FAIR principles: Zenodo (www.zenodo.org) and Polish Polar Database (https://ppdb.us.edu.pl/): meteorological data: https://doi.org/10.5281/zenodo.5791748 (Ignatiuk, 2021a), glaciological data: https://doi.org/10.5281/zenodo.5792168 (Ignatiuk, 2021b). In addition, the glacier mass balance data are stored in the World Glacier Monitoring Service database (dx.doi.org/10.5904/wgms-fog-2021-05, WGMS, 2021).

All the data are also available through the Svalbard Integrated Arctic Earth Observing System (SIOS) data access portal (https://sios-svalbard.org/metsis/search).

\section{Summary}

This paper has presented details of the glaciological and meteorological dataset (2009-2020) from the Werenskioldbreen (Svalbard). The meteorological dataset includes 10 minutes, hourly and daily air temperature, relative humidity, short- and long-wave radiation, wind speed and its direction. The glaciological dataset includes point mass balance (winter, summer, net), snow depth, bulk density and snow water equivalent (SWE) for the mass-balance stakes, annual surface mass balance (SMB) 345 and modelled daily surface ablation. These data allow observations of the rapid changes taking place in the Arctic. In particular, they allow determining the rate of climate change directly on glaciers. Werenskioldbreen mass loss (SMB) is accelerating at a rate of $-0.23 \mathrm{~m}$ w.e. for a decade. This is the result of air temperature increase $\left(0.09^{\circ} \mathrm{C}\right.$ per year $)$, which is over five times faster 
https://doi.org/10.5194/essd-2021-464

Preprint. Discussion started: 5 January 2022

(c) Author(s) 2022. CC BY 4.0 License.

(c) (i)

than the global average of $0.17^{\circ} \mathrm{C}$ per decade (NOAA, 2020). These high-quality and long-term observation data have been already used to assess the hydrological models and glaciological studies. The objective of releasing these data is to improve the usage of this data to calibration and validation of the remote sensing products, models as well as to increase data reuse.

\section{Acknowledgements}

The study presents part of the results from the project "Hindcasting and projections of hydro-climatic conditions of Southern Spitsbergen” (grant no. 2017/27/B/ST10/01269) financed by the Polish National Science Centre and the "Arctic climate system study of ocean, sea ice, and glaciers interactions in Svalbard area"-AWAKE2 (Pol-Nor/198675/ 17/2013), supported by the National Centre for Research and Development within the Polish-Norwegian Research Cooperation Programme and the SvalGlac-Sensitivity of Svalbard glaciers to climate change, the ESF Project. Glaciological and meteorological data have been processed under assessment of the University of Silesia in Katowice data repository within the project Integrated Arctic Observing System (INTAROS). This project has received funding from the European Union's Horizon 2020 research and innovation programme under grant agreement No. 727890. A legacy from the ice2sea 7th FP and the ESF SvalGlac projects was used. The studies were carried out as part of the scientific activity of the Centre for Polar Studies (University of Silesia in Katowice) with the use of research and logistic equipment (GPR set, GNSS receivers snowmobiles and supporting equipment) of the Polar Laboratory of the University of Silesia in Katowice

The authors would like to thank the employees, doctoral students and students of the University of Silesia in Katowice for their help in the field work. We would also like to thank our colleagues from the University of Wrockaw for their hospitality at the Polar Station. Stanisław Baranowski Spitsbergen and excellent cooperation. Also thanks to the members of the expedition from the Polish Polar Station Hornsund for their cooperation.

\section{Competing interests.}

The contact author has declared that neither they nor their co-authors have any competing interests

\section{Author Contribution}

370 DI- Conceptualization, Formal analysis, Methodology, Validation, Writing - original draft preparation, review \& editing. MB - Investigation, Methodology, Writing - review \& editing. TB - Data curation, Investigation, Writing - review \& editing. MG - Investigation, Methodology, Validation, Writing - review \& editing. JJ - Conceptualization, Funding acquisition, Supervision, Writing - review \& editing. MK - Formal analysis, Investigation, Writing - original draft preparation. ML Investigation, Validation, Writing - review \& editing. ŁM - Data curation, Formal analysis, Writing - original draft preparation, review \& editing. ŁS - Investigation, Writing - review \& editing. 
https://doi.org/10.5194/essd-2021-464

Preprint. Discussion started: 5 January 2022

(c) Author(s) 2022. CC BY 4.0 License.

\section{References}

Baranowski, S.: Naled Ice in Front of Some Spitsbergen Glaciers, J. Glaciol., 28, 211-214, https://doi.org/https://doi.org/10.3189/S0022143000011928, 1982.

Błaszczyk, M., Ignatiuk, D., Grabiec, M., Kolondra, L., Laska, M., Decaux, L., Jania, J., Berthier, E., Luks, B., Barzycka, B. and Czapla, M.: Quality Assessment and Glaciological Applications of Digital Elevation Models Derived from Space-Borne and Aerial Images over Two Tidewater Glaciers of Southern Spitsbergen, Remote Sens., 11, 1121, https://doi.org/10.3390/RS11091121, 2019.

Błaszczyk, M., Jania, J. A., Ciepły, M., Grabiec, M., Ignatiuk, D., Kolondra, L., Kruss, A., Luks, B., Moskalik, M., Pastusiak, T., Strzelewicz, A., Walczowski, W. and Wawrzyniak, T.: Factors Controlling Terminus Position of Hansbreen, a Tidewater

385 Glacier in Svalbard, J. Geophys. Res. Earth Surf., 126, e2020JF005763, https://doi.org/10.1029/2020JF005763, 2021.

Błaszczyk, M., Jania, J. A. and Kolondra, L.: Fluctuations of tidewater glaciers in Hornsund Fjord (Southern Svalbard) since the beginning of the 20th century, Polish Polar Res., 34, 327-352, https://doi.org/10.2478/popore-2013-0024, 2013.

Box, J. E., Colgan, W. T., Wouters, B., Burgess, D. O., O’Neel, S., Thomson, L. I. and Mernild, S. H.: Global sea-level contribution from Arctic land ice: 1971 to 2017, Environ. Res. Lett., 13, 1-11, https://doi.org/10.1088/1748-9326/AAF2ED, 2019.

Braithwaite, R. J.: Positive degree-day factors for ablation on the Greenland ice sheet studied by energy-balance modelling, J. Glaciol., 41, 153-160, https://doi.org/10.1017/S0022143000017846, 1995.

Braithwaite, R. J. and Olesen, O. B.: Calculation of glacier ablation from air temperature, West Greenland, in: Glacier fluctuations and climatic change, edited by Oerlemans, J., Kluwer Academic Publishers, Dordrecht, 219-233, available at: https://www.research.manchester.ac.uk/portal/en/publications/calculation-of-glacier-ablation-from-air-temperature-westgreenland(5823a1a2-551e-4270-8d60-b5d23422ebdb)/export.html (last access: 23 December 2021), 1989.

Cogley, J. G., Hock, R., Rasmussen, L. A., Arendt, A. A., Bauder, A., Jansson, P., Braithwaite, R. J., Kaser, G., Möller, M., Nicholson, L. and Zemp, M.: Glossary of glacier mass balance and related terms, IHP-VII Te., UNESCO-IHP, Paris, available at: https://unesdoc.unesco.org/ark:/48223/pf0000192525 (last access: 23 December 2021), 2011.

400 Grabiec, M., Ignatiuk, D., Jania, J. A., Moskalik, M., Głowacki, P., Błaszczyk, M., Budzik, T. and Walczowski, W.: Coast formation in an Arctic area due to glacier surge and retreat: The Hornbreen-Hambergbreen case from Spistbergen, Earth Surf. Process. Landforms, 43, 387-400, https://doi.org/10.1002/ESP.4251, 2018.

Grabiec, M., Budzik, T. and Głowacki, P.: Modeling and Hindcasting of the Mass Balance of Werenskioldbreen (Southern Svalbard), 44, 164-179, https://doi.org/10.1657/1938-4246-44.2.164, 2018.

405 Gwizdała, M., Jeleńska, M. and Łęczyński, L.: The magnetic method as a tool to investigate the Werenskioldbreen environment (south-west Spitsbergen, Arctic Norway), Polar Res., 37, 1-9, https://doi.org/10.1080/17518369.2018.1436846, 2018. 
https://doi.org/10.5194/essd-2021-464

Preprint. Discussion started: 5 January 2022

(c) Author(s) 2022. CC BY 4.0 License.

Hanssen-Bauer, I., Førland, E.J., Hisdal, H., Mayer, S., Sandø, A.B. and Sorteberg, A. (Eds.): Climate in Svalbard 2100 - a knowledge base for climate adaptation, Norway, Norwegian Centre of Climate Services (NCCS) for Norwegian Environment Agency (Miljødirektoratet), 208pp, (NCCS report 1/2019), https://doi.org/10.25607/OBP-888, 2019.

Ignatiuk, D.: Meteorological data from the Werenskioldbreen (Svalbard) 2009-2020 [Data set]. Zenodo. https://doi.org/10.5281/zenodo.5791748, 2021a.

Ignatiuk, D.: Glaciological data (point mass balance, SWE, snow depth, bulk snow density, modelled runoff) from Werenskioldbreen (Svabard) 2009-2020 [Data set]. Zenodo. https://doi.org/10.5281/zenodo.5792168, 2021b.

Ignatiuk, D., Piechota, A., Ciepły, M. and Luks, B.: Changes of altitudinal zones of Werenskioldbreen and Hansbreen in period

4151990 - 2008, Svalbard, AIP Conf. Proc., 1618, 280, https://doi.org/10.1063/1.4897727, 2015.

IPCC: The Ocean and Cryosphere in a Changing Climate 2019, https://www.ipcc.ch/srocc/home/, last access: 1 April 2020.

Hock, R.: Temperature index melt modelling in mountain areas, J. Hydrol., 282, 104-115, https://doi.org/10.1016/S00221694(03)00257-9, 2003.

Isaksen, K., Nordli, Førland, E. J., Łupikasza, E., Eastwood, S. and Niedźwiedź, T.: Recent warming on Spitsbergen-

Influence of atmospheric circulation and sea ice cover, J. Geophys. Res. Atmos., 121, 11913-11931, https://doi.org/10.1002/2016JD025606, 2016.

Jania, J., Majchrowska, E., Ignatiuk, D., Marszałek, H. and Wąsik, M.: Seasonal and interannual variability in runoff from the Werenskioldbreen catchment, Spitsbergen, Polish Polar Res., 36, 197-224, https://doi.org/10.1515/popore-2015-0014, 2015. Łepkowska, E. and Stachnik, L.: Which Drivers Control the Suspended Sediment Flux in a High Arctic Glacierized Basin (Werenskioldbreen, Spitsbergen)?, Water, 10, 1408, https://doi.org/10.3390/W10101408, 2018.

Łupikasza, E. B., Ignatiuk, D., Grabiec, M., Cielecka-Nowak, K., Laska, M., Jania, J., Luks, B., Uszczyk, A. and Budzik, T.: The Role of Winter Rain in the Glacial System on Svalbard, Water, 11, 334, https://doi.org/10.3390/W11020334, 2019.

Majchrowska, E., Ignatiuk, D., Jania, J., Marszałek, H. and Wasik, M.: Seasonal and interannual variability in runoff from the Werenskioldbreen catchment, Spitsbergen, Polish Polar Res., 36, 197-224, https://doi.10.1515/popore-2015-0014, 2015.

NOAA: National Centers for Environmental information, Climate at a Glance, Global Time Series, available at: https://www.ncdc.noaa.gov/cag/, last access: 23 October 2021.

Noël, B., Jakobs, C. L., van Pelt, W. J. J., Lhermitte, S., Wouters, B., Kohler, J., Hagen, J. O., Luks, B., Reijmer, C. H., van de Berg, W. J. and van den Broeke, M. R.: Low elevation of Svalbard glaciers drives high mass loss variability, Nat. Commun., 11, 4597, https://doi.org/10.1038/s41467-020-18356-1, 2020.

435 Nordli, Ø., Przybylak, R., Ogilvie, A. E. J. and Isaksen, K.: Long-term temperature trends and variability on spitsbergen: The extended svalbard airport temperature series, 1898-2012, Polar Res., 33, 1898-2012, https://doi.org/10.3402/POLAR.V33.21349/SUPPL_FILE/ZPOR_A_11818879_SM0001.PDF, 2014.

Nuth, C., Gilbert, A., Köhler, A., McNabb, R., Schellenberger, T., Sevestre, H., Weidle, C., Girod, L., Luckman, A. and Kääb, A.: Dynamic vulnerability revealed in the collapse of an Arctic tidewater glacier, Sci. Reports 9, 5541, 440 https://doi.org/10.1038/s41598-019-41117-0, 2019. 
https://doi.org/10.5194/essd-2021-464

Preprint. Discussion started: 5 January 2022

(c) Author(s) 2022. CC BY 4.0 License.

Ohmura, A.: Physical basis for the temperature-based melt-index method, J. Appl. Meteorol., 40, 753-761, https://doi.org/10.1175/1520-0450(2001)040<0753:PBFTTB>2.0.CO;2, 2001.

Osuch, M. and Wawrzyniak, T.: Inter- and intra-annual changes in air temperature and precipitation in western Spitsbergen, Int. J. Climatol., 37, 3082-3097, https://doi.org/10.1002/JOC.4901, 2017.

445 Pälli, A., Moore, J. C., Jania, J., Kolondra, L. and Głowacki, P.: The drainage pattern of Hansbreen and Werenskioldbreen, two polythermal glaciers in Svalbard, Polar Res., 22, 355-371, https://doi.org/10.1111/j.1751-8369.2003.tb00117.x, 2003.

Schuler, T. V., Kohler, J., Elagina, N., Hagen, J. O. M., Hodson, A. J., Jania, J. A., Kääb, A. M., Luks, B., Małecki, J., Moholdt, G., Pohjola, V. A., Sobota, I. and Van Pelt, W. J. J.: Reconciling Svalbard Glacier Mass Balance, Front. Earth Sci., 8, 156, https://doi.org/10.3389/FEART.2020.00156/BIBTEX, 2020.

450 Stachnik, L., Majchrowska, E., Yde, J. C., Nawrot, A. P., Cichała-Kamrowska, K., Ignatiuk, D. and Piechota, A.: Chemical denudation and the role of sulfide oxidation at Werenskioldbreen, Svalbard, J. Hydrol., 538, 177-193, https://doi.org/10.1016/J.JHYDROL.2016.03.059, 2016a.

Stachnik, Ł., Yde, J. C., Kondracka, M., Ignatiuk, D. and Grzesik, M.: Glacier naled evolution and relation to the subglacial drainage system based on water chemistry and GPR surveys (Werenskioldbreen, SW Svalbard), Ann. Glaciol., 57, 19-30,

455 https://doi.org/10.1017/AOG.2016.9, 2016b.

Stachnik, Ł., Yde, J. C., Nawrot, A., Uzarowicz, Ł., Łepkowska, E. and Kozak, K.: Aluminium in glacial meltwater demonstrates an association with nutrient export (Werenskiöldbreen, Svalbard), Hydrol. Process., 33, 1638-1657, https://doi.org/10.1002/HYP.13426, 2019.

Sturm, M., Taras, B., Liston, G. E., Derksen, C., Jonas, T. and Lea, J.: Estimating Snow Water Equivalent Using Snow Depth

Data and Climate Classes, J. Hydrometeorol., 11, 1380-1394, https://doi.org/10.1175/2010JHM1202.1, 2010.

Sułowicz, S., Bondarczuk, K., Ignatiuk, D., Jania, J. A. and Piotrowska-Seget, Z.: Microbial communities from subglacial water of naled ice bodies in the forefield of Werenskioldbreen, Svalbard, Sci. Total Environ., 723, 138025, https://doi.org/10.1016/J.SCITOTENV.2020.138025, 2020.

Uszczyk, A., Grabiec, M., Laska, M., Kuhn, M. and Ignatiuk, D.: Importance of snow as component of surface mass balance 465 of Arctic glacier (Hansbreen, southern Spitsbergen), Polish Polar Res., 40, 311-338, https://doi.org/10.24425/PPR.2019.130901, 2019.

Van Pelt, W., Pohjola, V., Pettersson, R., Marchenko, S., Kohler, J., Luks, B., Ove Hagen, J., Schuler, T. V., Dunse, T., Noël, B. and Reijmer, C.: A long-term dataset of climatic mass balance, snow conditions, and runoff in Svalbard (1957-2018), Cryosphere, 13, 2259-2280, https://doi.org/10.5194/TC-13-2259-2019, 2019.

470 Walczowski, W., Beszczynska-Möller, A., Wieczorek, P., Merchel, M. and Grynczel, A.: Oceanographic observations in the Nordic Sea and Fram Strait in 2016 under the IO PAN long-term monitoring program AREX, Oceanologia, 59, 187-194, https://doi.org/10.1016/J.OCEANO.2016.12.003, 2017.

Wawrzyniak, T. and Osuch, M.: A 40-year High Arctic climatological dataset of the Polish Polar Station Hornsund (SW Spitsbergen, Svalbard), Earth Syst. Sci. Data, 12, 805-815, https://doi.org/10.5194/ESSD-12-805-2020, 2020. 
https://doi.org/10.5194/essd-2021-464

Preprint. Discussion started: 5 January 2022

(C) Author(s) 2022. CC BY 4.0 License.

(c) (1)

475 Wawrzyniak, T., Osuch, M., Napiórkowski, J. and Westermann, S.: Modelling of the thermal regime of permafrost during 1990-2014 in Hornsund, Svalbard, Polish Polar Res., 37, 219-242, https://doi.org/10.1515/POPORE-2016-0013, 2016.

WGMS: Fluctuations of Glaciers Database. World Glacier Monitoring Service, Zurich, Switzerland. DOI:10.5904/wgms-fog2021-05, 2021. 